\title{
Systematic Review on Farmers' Perceptions, Preferences and Utilization Patterns of Taro [Colocasia esculenta (L.) Scott] for Food and Nutrition Security in Nigeria
}

\author{
Tilahun Wondimu Fufa ${ }^{1, ~ *}$, Happiness Ogba Oselebe ${ }^{2}$, Catherine Veronica Nnamani ${ }^{3}$, \\ Celestine Azubuike Afiukwa ${ }^{4}$, Edak Aniedi Uyoh $^{5}$ \\ ${ }^{1}$ Departement of Horticulture, Oromia Agricultural Research Institute, Addis Ababa, Ethiopia \\ ${ }^{2}$ Departement of Crop Production and Landscape Management, University of Ebonyi State, Abakaliki, Nigeria \\ ${ }^{3}$ Department of Applied Biology, University of Ebonyi State, Abakaliki, Nigeria \\ ${ }^{4}$ Department of Biotechnology, University Ebonyi State, Abakaliki, Nigeria \\ ${ }^{5}$ Department of Genetics and Biotechnology, University of Calabar, Calabar, Nigeria
}

Email address:

bekatilahun@gmail.com (T. W. Fufa), h.oselebe@gmail.com (H. O. Osolebe),drnnamanikate@gmail.com (C. V. Nnamani), afikwa@yahoo.com (C. A. Afiukwa), edakuyoh@unical.edu.ng (E. A. Uyoh)

${ }^{*}$ Corresponding author

\section{To cite this article:}

Tilahun Wondimu Fufa, Happiness Ogba Oselebe, Catherine Veronica Nnamani, Celestine Azubuike Afiukwa, Edak Aniedi Uyoh. Systematic Review on Farmers' Perceptions, Preferences and Utilization Patterns of Taro [Colocasia esculenta (L.) Scott] for Food and Nutrition Security in Nigeria. Journal of Plant Sciences. Vol. 9, No. 4, 2021, pp. 224-233. doi: 10.11648/j.jps.20210904.23

Received: June 12, 2021; Accepted: June 28, 2021; Published: August 31, 2021

\begin{abstract}
Malnutrition afflicts a large number of people in Sub-Saharan Africa. Orphan crops, such as Taro plants, can play critical roles in ensuring global food and nutritional security in this regard. Nigeria is the world's leading producer of taro. It is primarily consumed as a main component or as a soup thickener by resource-poor rural residents in Nigeria's south-eastern regions. The corm contains a lot of carbohydrates, while the leaves have a lot of protein. Furthermore, its social and medicinal importance should not be overlooked. It is, however, a food resource that is underutilized and receives little attention from scientists. Farmers cultivate it on a small scale, and its commercial importance is primarily limited to the local area, implying that farmers are the primary users and keepers of taro genetic diversity. As a result, they've gained some valuable experience in identifying and preserving cultivars they prefer, as well as developing utilization patterns (culinary diversity) for the cultivars they've kept. Information on farmers' knowledge of taro utilization patterns, cultivar maintenance, and culinary diversity is scarce in Nigeria, particularly in the south-eastern region. The purpose of this study is to review existing literature on farmers' and consumers' perceptions and preferences for taro in order to provide insight into knowledge of taro food use, benefits, and potential brand foods. It also addresses key bottlenecks that impede taro production and consumption in Nigeria, paving the way for increased taro production and adoption by both farmers and consumers.
\end{abstract}

Keywords: Colocasia esculenta, Cultivar Maintenance, Farmers' Knowledge, Food Security, Nutritional Security, Taro

\section{Introduction}

Taro [Colocasia esculenta (L.) Scott] is a 9,000-year-old ariod food crop with a 2000-year cultivation history [1]. Although it is thought to have originated in South Central Asia, most likely in India, high diversity has been reported in South East Asia [2]. It has spread throughout the world and is now a major crop in Asia, the Pacific, Africa, and the Caribbean.
Taro was first discovered in West Africa at least 2000 years ago. Globally, approximately 10.64 million tons of Taro were produced from 1.66 million hectares, with an average yield of 9.5 tha $^{-1}$ [3]. In the same year, Nigeria, the world's largest taro producer, harvested approximately 3.33 million tons from 0.72 million hectares, with an average yield of 4.14 tha $^{-1}$.

Taro is a staple food, mainly for resource-poor rural inhabitants [4], and is regularly consumed as a main 
component or as a soup thickener in the south-eastern parts of Nigeria [5]. Primarily, taro is grown for its starchy corm [6] and sometimes the leaves, petioles and inflorescences are also edible [1]. It has a high mineral and vitamin content while having a low fat, fiber, and ash content. It can help diabetics, the elderly, children with allergies, and others with intestinal problems [7]. Taro is a sacred plant with high prestige and cultural and symbolic significance in many cultures. As a result, the value of taro for national, regional, and global food and nutritional security cannot be overstated.

More than 30,000 plant species are thought to be edible in the biosphere [8]. Taro is ranked $19^{\text {th }}$ among the world's 20 major edible food crops [9]. It was one of the third most consumed staple food crops in Nigeria between 1970 and 1980, and it was celebrated yearly at a festival called "Ede Oye" in the country's southern regions [5]. Despite its growing importance as a crop in many parts of the world, as well as its cultural significance among users, the International Agricultural Research Center (CGIAR) lacks a mandate to conserve and conduct research on taro [10]. The Philippine Root Crop Research and Training Center (Bey Bey, Philippines), the Koronivia Research Station (Fiji), the Bubia Agricultural Research Centre (Papua New Guinea), and numerous other locations in Oceania have all made efforts [11]. Similarly, there is no Nigerian Germplasm Repository in charge of preserving and disseminating taro germplasm. The International Institute of Tropical Agriculture (IITA) and the National Root Crop Research Institute of Nigeria worked together to collect and preserve taro landraces. However, they lost all of the taro genetic materials during the outbreak of taro leaf blight disease in West Africa [12]. Thus, farmers have maintained taro for many years, and taro genetic resources have largely remained under the control of local communities. It is grown by small-scale farmers [4], and its commercial significance is primarily local. This implies that farmers have been the primary users and guardians of taro genetic diversity. In doing so, they have accumulated some reasonable experience identifying and maintaining cultivars they prefer, as well as developing utilization patterns (culinary diversity) for the cultivars they have maintained. To the best of the authors' knowledge, information on farmer's knowledge on taro utilization patterns, cultivar maintenance and culinary diversity in Nigeria, specifically in south eastern parts is scanty. Therefore, this paper reviews farmer's knowledge on utilization patterns and cultivar maintenance of taro. It also addresses key bottlenecks that hinder up-scaling of production and consumption of taro and proffers the way forward for an up-scale production and increased adoption of taro by both farmers and consumers in Nigeria.

\section{The Taro}

\subsection{Nomenclature of Taro}

Cocoyam is a generic term for several tropical root crops and vegetable crops in the arum family [13]. Colocasia esculenta is the scientific name for cultivated taro, and the species is polymorphic, with two botanical varieties or forms, namely Colocasia esculenta var. esculenta (dasheen) and $C$. esculenta var. antiquroum (eddoe) [14]. Most West African communities refer to these varieties as cocoyam, but each species has its own set of local, traditional, and scientific names. This, combined with morphological similarities between species within a genus, has contributed to confusion in the use of terminologies for identification. The existing confusion about its taxonomy and nomenclature, on the other hand, is a major impediment to utilizing available scientific data from various areas in order to fully exploit the Colocasia species' potential.

\subsection{Variability in Taro}

According to the author's preliminary survey, farmers and consumers in Nigeria have their own markers for selecting taro cultivars for their intended uses and maintenance, despite the fact that the information is sparse and poorly documented. In Igbo land, for example, growers choose and maintain taro based on morphological characteristics such as petiole color, bud color, plant vigor, corm size, corm shape, taro's irritating nature (acridity), and cooking times. In the same location, they also have their own indicators for selecting and purchasing taro corms on the market, such as bud color, corm size, and shapes. Similarly, Jianchu et al. [15] studied taro diversity in China's Yunnan Province and discovered five uses based on morphotypes of taro as classified by farmers: (1) inflorescence, which produces abundant flowers eaten as a vegetable; (2) single corm, of up to $2 \mathrm{~kg}$ fresh weight with few cormels; (3) multicormel, which has many cormels with better quality and yield than the corm; (4) multicorm, which has similar sized corms and cormels; and (5) petiole, where that structure is eaten as a vegetable but corms are poorly developed and long stolon's are produced. Many researchers have also reported the presence of high variability in the taro using morphological markers [16]. Corm color, corm shape, corm size, petiole length, number of petioles, petiole color, corm flesh color, leaf color, leaf shape, corm weight, stolon formation [17-19], and flower formation [20] are just a few of the morphological markers.

\section{Existing Knowledge and Uses of Taro}

\subsection{Local Cultivar Maintenance and Agricultural Practices Applied by Farmers}

Where taro is still grown, there is a trend toward replacing traditional cultivars with a smaller number of varieties that have been selected or bred for high yield. Yam and taro reigned supreme in the southern parts of Nigeria for many years, specifically from 1965 to 1980 [5]. Taro was the queen and yam was the king. They were the preferred staple food at the time, and they were even offered to the gods. The arrival and domestication of the easy growers (plantain, banana, maize, and later cassava, Tania, and sweet potato) posed a challenge to their acceptance and ascendency [5]. Easy-to-grow foods gained recognition and prominence as staple foods, eventually displacing earlier staples. The loss of traditional diversity could have serious ramifications. 
It may imply that cultivars will not be available for evaluation in the face of severe pest outbreaks, or the need for new ecological adaptations or quality characteristics. Furthermore, as production declines, traditional knowledge of varieties and cultivation practices will be lost. Singh et al. [21], on the other hand, reported a high level of diversity among farmer cultivars. Thus, documenting farmers' experience and practice in cultivar maintenance and utilization could be beneficial to the future of taro breeding and improvement programs.

Ex-situ and in-situ methods are used for Taro genetic resource conservation. The appropriate balance of methods used is determined by factors such as the biological characteristics of the gene pool, infrastructure and human resources, the number of accessions in each collection and its geographic location, and the intended use of the conserved germplasm [22]. Ex-situ conservation makes it impossible to collect and conserve all taro genetic diversity, whereas on-farm conservation, including home gardens, can help taro growers gain access to a much wider genetic diversity while also benefiting them [23]. The same authors discussed the importance of home gardens in the Pacific region, which includes Papua New Guinea, Fiji, and Tonga. Home gardening is another popular conservation method used by growers in south-eastern Nigeria to preserve taro genetic resources. They use traditional storage structures to conserve taro for the following growing season. Growers in Igbo land, for example, pile taro corms under shade or cover them with straw or plantain leaves (Figure 1). In the same region, little is known about the extent of taro diversity in home gardens. Furthermore, the efficacy of their storage is not assessed, which may have some limitations. Traditional storage, for example, has no roof or a water-proof roof, no ventilation, and may result in early sprouting and rotting. Farmers occasionally add wood ash to taro heaps in the hope of reducing fungus development in taro storage. Taro was also stored in pits that were covered by leaves and soil by some farmers.

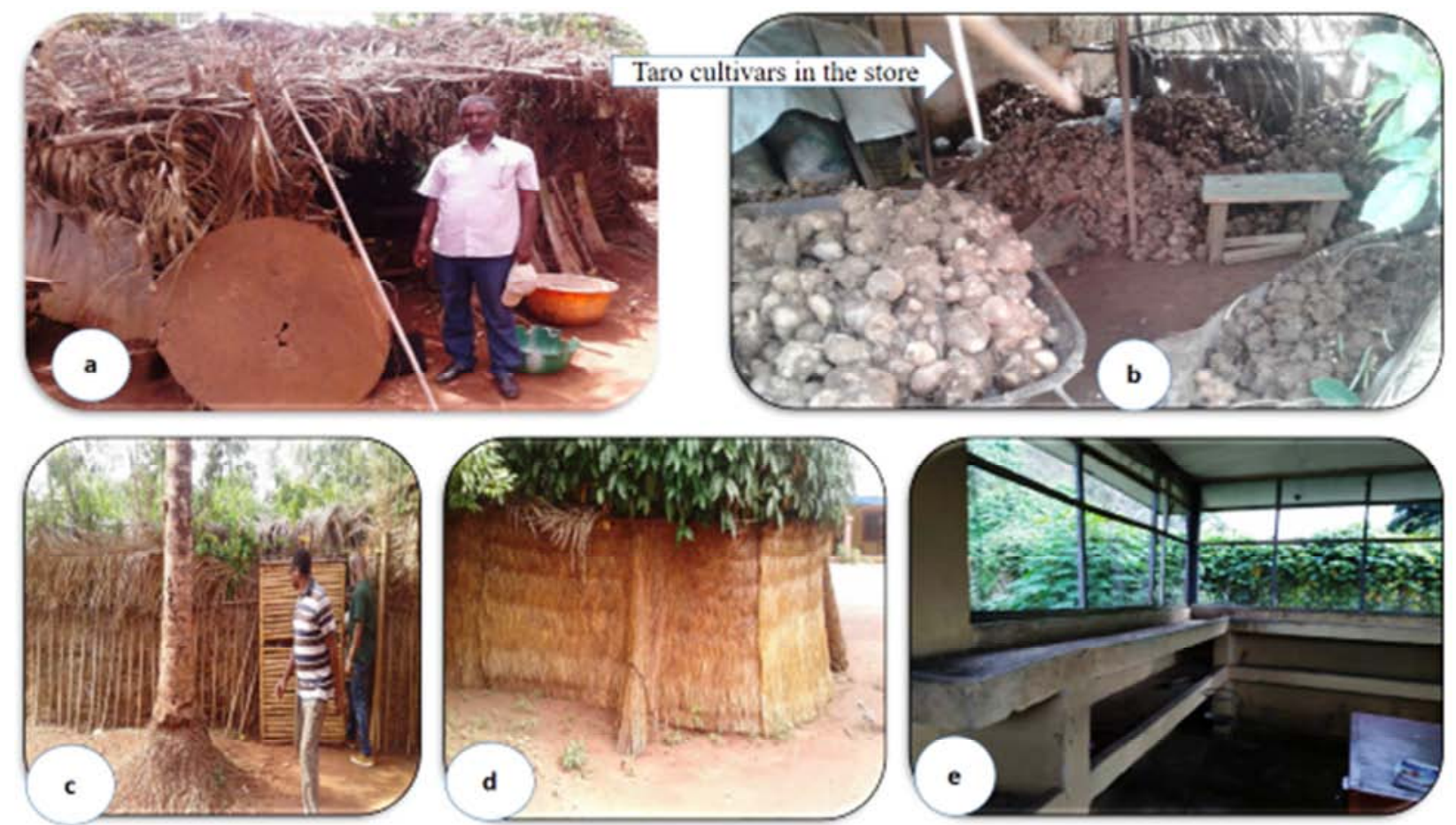

Figure 1. Traditional and improved taro barn (Photo: Fufa, 2018); $a, b \& c=$ different traditional taro barn made of stick and palm leaves, $d=$ traditional taro

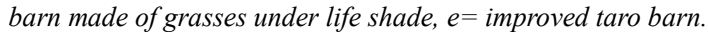

\subsection{Perceptions and Preferences of Taro Utilizations}

Farmers' preference for taro genetic material conservation is primarily motivated by utilization concerns. Farmers, for example, prefer taro based on the use and color of the petiole. Farmers in Nigeria use corms for fufu while cormels are used for soup thickening, possibly due to the former's higher dry matter content than the latter. Taro with a pink petiole can be used to make fufu, whereas the others are only used to make soup. Taro with a purple corm color is also preferred in Hawaii for the production of poi [10. Similarly, the extracted starch content of the taro corm has been reported to be $28.3 \%$ for pink taro and $27 \%$ for white taro [24]. Taro consumption is also influenced by acridity factors, which cause sharp irritation and burning sensations in the throat and mouth upon ingestion [25]. For this and other reasons, farmers and consumers prefer taro that is non-irritant and easy to cook with less energy. Furthermore, farmers prefer robust taro genotypes that are both healthy and yielding. Paul and Miah [26] reported a positive and strong correlation between plant vigor (height) and corm yield in taro. Thus, designing taro improvements for plant architecture, corm yield, disease, and quality traits is advised. 


\section{Uses and Utilization}

\subsection{Nutritional Profile of Taro}

Table 1. Nutritional content of major root crops grown in Africa.

\begin{tabular}{|c|c|c|c|c|}
\hline Nutrients (Per $100 \mathrm{~g})$ & Sweet Potato & Cassava & Yam & Taro \\
\hline Energy (kcal) & 86.00 & 160.00 & 118.00 & 112.00 \\
\hline Protein $(\mathrm{g})$ & 1.60 & 1.40 & 1.50 & 1.50 \\
\hline Total lipid (g) & 0.10 & 0.30 & 0.20 & 0.29 \\
\hline Carbohydrate, by difference (g) & 20.10 & 38.10 & 27.90 & 26.46 \\
\hline Fiber, total dietary $(\mathrm{g})$ & 3.00 & 1.80 & 4.10 & 4.19 \\
\hline Sugars, total (g) & 4.20 & 1.70 & 0.50 & $\mathrm{~N}$ \\
\hline Calcium (mg) & 30.00 & 16.00 & 17.00 & 43.00 \\
\hline Potassium (mg) & 337.00 & 271.00 & 816.00 & 591.00 \\
\hline Phosphorus (mg) & 47.00 & 27.00 & 55.00 & 70.00 \\
\hline Sodium (mg) & 55.00 & 14.00 & 9.00 & 82.00 \\
\hline Total ascorbic acid (mg) & 2.40 & 20.60 & 17.10 & 4.50 \\
\hline Thiamin (mg) & 0.08 & 0.09 & 0.11 & 0.09 \\
\hline Riboflavin (mg) & 0.06 & 0.05 & 0.03 & $\mathrm{~N}$ \\
\hline Niacin (mg) & 0.56 & 0.85 & 0.55 & 0.60 \\
\hline Vitamin E (mg) & 0.26 & 0.19 & 0.35 & 4.50 \\
\hline Vitamin K $(\mu \mathrm{g})$ & 1.80 & 1.90 & 2.30 & 1.00 \\
\hline Sources & {$[28]$} & & & [29] \\
\hline
\end{tabular}

Table 2. Common taro recipes of the globe, preparation mechanism and parts used.

\begin{tabular}{|c|c|c|}
\hline Country & Food type & Utilization \\
\hline \multirow[t]{7}{*}{ India } & Kosu/patode & $\begin{array}{l}\text { Patode, a dish made with chilies and carom seeds, is prepared by rolling leaves in flour pounds and then frying and } \\
\text { steaming them. }\end{array}$ \\
\hline & Patrada & The leaves are steamed and eaten \\
\hline & Alu chiwadi & The leaves de-veined, rolled with flour, red chills, spices, salt and steamed \\
\hline & kachaloo & To make kachaloo, the plant's leaves are mashed and fried with spices \\
\hline & Kerala & Kerala is a vegetable dish made from the leaves and petioles of certain varieties of taro \\
\hline & Porridge & The taro corm is boiled in salty water in pots to make porridge \\
\hline & Gava & Gava is made by steaming young taro leaves, drying them in the sun, and storing it for later use \\
\hline Nepal & Maseura & Maseura is a cake made from chopped dried taro leaves and petiole \\
\hline Bangladesh & Sauce & Taro corms are simmered in a rich curry sauce \\
\hline Romans & Apicius & Apicius is a sauce made of pepper, cumin, rue, vinegar, oil, and liquamen that is served with chopped boiled taro pieces \\
\hline Maldives & Curry, chips, boiled & $\begin{array}{l}\text { Taro corms are steamed or cooked with salt to taste and served with grated coconut, chili paste, and fish soup. It is also } \\
\text { made into a curry, and the corms are sliced and fried to make chips, as well as used to make a variety of sweets }\end{array}$ \\
\hline China & Taro dumpling & $\begin{array}{l}\text { Taro corms are frequently braised with either pork or beef. It's used to make taro dumplings, a small plated dish, and } \\
\text { taro cake, a pan-fried dish. Taro cake is a delicacy that is eaten during the Chinese New Year }\end{array}$ \\
\hline Polynesia & $\begin{array}{l}\text { Poi, samoan, laulau, } \\
\text { lupulu }\end{array}$ & $\begin{array}{l}\text { Poi, the famous Hawaiian staple, is made by mashing steamed taro corms with water. Samoan "fa'ausi" is grated, } \\
\text { cooked taro mixed with coconut milk and brown sugar. Taro plant leaves are also used in Polynesian cooking, } \\
\text { particularly as edible wrappings for dishes such as Hawaiian laulau, Fijian and Samoan "palusami" (wrapped coconut } \\
\text { milk and onions), and Tongan "lupulu" (wrapped corned beef) }\end{array}$ \\
\hline Nigeria & $\begin{array}{l}\text { Bitter leaf Soup, Ora } \\
\text { Soup and ekpang } \\
\text { nkukwo (Rivers } \\
\text { Native Soup) }\end{array}$ & Corms are boiled and used in soup alongside other vegetables \\
\hline Taiwan & Chips & $\begin{array}{l}\text { Chips are typically made from upland taro corms due to their lower moisture content. Taro chips are harder and have a } \\
\text { stronger nutty flavor }\end{array}$ \\
\hline Japan & Varieties of dish & $\begin{array}{l}\text { Taro corm is typically cooked, but it can also be grated and eaten raw or steamed. The petiole was also used to prepare } \\
\text { a variety of recipes }\end{array}$ \\
\hline $\begin{array}{l}\text { South } \\
\text { Korea }\end{array}$ & Varieties of dish & $\begin{array}{l}\text { The corm has been stewed, and the leaf stem has been stir-fried. Taro corms are also used medicinally, particularly to } \\
\text { treat insect bites. Taro corm is known as "egg from the earth." }\end{array}$ \\
\hline Vietnam & Variety of dish & Taro corm is a filling that is used in spring rolls, cakes, puddings, soups, and other desserts \\
\hline $\begin{array}{l}\text { United } \\
\text { states }\end{array}$ & Poi, chips, flour & $\begin{array}{l}\text { Poi is a purplish paste made from cooked taro that is produced in Hawaii. It ferments naturally or is consumed } \\
\text { unfermented. The corm is dried and used to make flour in place of potatoes. When combined with wheat flour, dasheen } \\
\text { flour is said to produce excellent pancakes }\end{array}$ \\
\hline Philippines & $\begin{array}{l}\text { Laing, sinigang, } \\
\text { ginataan }\end{array}$ & $\begin{array}{l}\text { Taro petiole and leaf cooked in coconut milk and salted with fermented shrimp or fish bagoong are the main ingredients } \\
\text { of this dish. This sour stew can be made with either pork and beef, shrimp, or fish. Taro, which has been peeled and } \\
\text { diced, is a key ingredient in pork sinigang. Ginataan is a Filipino word that means "coconut milk cooked." }\end{array}$ \\
\hline
\end{tabular}


Taro is most commonly grown for its starchy corm. The leaves and flowers are occasionally eaten as vegetables [10]. Taro can help with food and nutritional security, both of which must be ensured [27]. Taro contains a greater variety of vitamins and nutrients than other root and tuber crops (Table 1). The corms primarily provide energy in the form of easily digestible starch. They have high carbohydrate content but a low fat and protein content. The corms also contain a variety of vitamins, amino acids, and minerals. Potassium is a mineral that is abundant. Taro leaf blades, stolons, and flower heads (inflorescences) are consumed in many parts of the world, but there is little information on their nutritional value and application.

\subsection{Potential Food Uses of Taro}

Taro has a greater culinary diversity and more easily digestible recipes than other root crops. Culinary diversity results from cultural diversity, edible parts used in recipe preparation, ingredients used in recipe preparation, and processing types (Table 2). Poi, chips, fufu, luau, achu, and sepal are some of the most popular recipes around the world [7]. Taro soups in Nigeria include bitter leaf soup, Ora soup, and ekpang nkukwo (river native soup). Poi is a purplish paste made from cooked taro that is produced in Hawaii. It ferments naturally or is consumed unfermented. Boiling corms are mashed to form a weaning diet in West Africa. In Nigeria, mature Aroids are ground into flour to make fufu, which is commonly eaten with stew. Taro chips are a popular product, and young taro leaves are an excellent vegetable in the South Pacific, where they are combined with coconut cream to make a dish known as "luau," which is eaten with boiled or roasted taro or banana. Achu is a nutritious meal made from pre-gelled taro that is popular in Cameroon. Sapal is a fermented dish made from taro corms and coconut cream. Taro leaves, despite their high protein content, are rarely used in Nigerian cuisine. Encouragement of the use of taro leaves can thus help to improve the nutritional security of rural poor farmers and consumers.

\section{Production Constraints}

The key bottlenecks that are impeding the expansion of taro production and consumption in Nigeria and around the world, as well as potential solutions, are summarized in (Table 3). A variety of biotic, abiotic, and social factors contribute to suboptimal taro production. These factors include a lack of improved varieties, pests and diseases, poor crop husbandry, changes in food habits, limited research attention, limited resource allocation, inefficient marketing, a lack of processing and innovative products, a scarcity of planting materials, high farm input costs, poor soil fertility, climate change, poor eating quality, less culinary diversity, and insufficient agronomic diversity. Possible recommendations include increasing yield, quality, pest and disease resistance, stress resistance, crop management practices, post-harvest handling, food processing, and culinary diversity. Furthermore, strong support for extension services, public awareness, input supply, credit facilities, marketing, and agricultural input subsidies were proposed. Low productivity, taro leaf blight, drought, anti-nutrients, germplasm resources, and utilization are among the many production constraints that must be addressed through well-designed breeding strategies.

\subsection{Low Yield}

Taro, like any other orphan crop, has seen little development in terms of improved varieties in Nigeria for a long time. Farmers have been growing the same old varieties, which has had a negative impact on yields. Farmers must also travel from farm to farm in order to obtain planting materials. Otherwise, they rely on volunteer seedlings, which aid in disease pathogen transmission. Improvement in agronomic practices is also limited. Soil nutrient depletion is a common occurrence. Farmers, on the other hand, consider fertilizer use on taro fields to be impractical and refuse to use it. The national average taro yield in Nigeria was estimated to be 4.14 tha $^{-1}$, which is significantly lower than the global average yield of 9.5 tha $^{-1}$ [3]. Taro, on the other hand, has a yield potential of $31 \mathrm{tha}^{-1}$ in Egypt and 50 tha $^{-1}$ in Hawaii with heavy fertilization [5]. Because the yield gap is so large, an investment in taro improvement could significantly contribute to the country's food and nutritional security.

\subsection{Diseases}

The most damaging disease, Phytophthora colocasiae leaf blight, causes low yield and poor quality corms [12]. Despite the fact that outbreaks of taro leaf blight diseases in West Africa are recent, they have demonstrated the devastating impact on the incomes and food security of small farmers who rely on the crop [21]. Taro leaves are lost in a short period of time during Phytophthora colocasiae epidemics, reducing taro corm yield by $50 \%$ and leaf yield by $95 \%$ [45] when compared to the age of taro leaves under normal survival conditions. Since the occurrence of taro leaf blight in Nigeria in 2009, taro production has declined by approximately $60 \%$, and total crop loss due to this disease is up to $50 \%$ in severe cases and more than $70 \%$ in extremely severe cases [12]. This pathogen can also cause rot on leaves, corms, flowers, petioles, and fruit (Figure 2).

Previous research, particularly in the Pacific, has demonstrated that management measures such as chemical and cultural practices are largely ineffective [12]. To overcome the challenge in Nigeria, Singh et al. [21] proposed natural selection of field resistant lines for Taro leaf blight and Mbong et al. [46] reported the most susceptible cultivars ("ebo coco") with $100 \%$ destruction and proposed horizontal resistance breeding using recurrent mass selection techniques. Misra et al. [47] also reported a gene $(\mathrm{S})$ that confers resistance to taro leaf blight disease and could be used. Corm rot is another significant disease in taro production. 


\subsection{Drought}

Drought and erratic rainfall are major constraints to upland taro production. Drought could diminish taro production by $40 \%$ [48], and this trend is anticipated to remain for the next 30 years due to climate variation [49]. As a result, breeders must urgently focus on the introduction of drought and heat resistant varieties in order to reduce yield loss due to climate change impacts. Significant research has been conducted on the problems and potential of root and tuber crop production, but little progress has been made in improving these crops' productivity under drought conditions. Taro's yield response to drought, in particular, is poorly understood [50]. There is little information available about the genetic control of drought tolerance in taro, making rapid screening of the crop impossible. Furthermore, little is known about the crop's drought resistance [51]. The establishment of crop drought stress conditions, as well as the detection of traits that can specifically discriminate in the variation of plant performance under drought, are two major issues that must be addressed.

\subsection{Post-Harvest Handling}

Because of their bulk and susceptibility to physical damage, taro and other edible Aroids are difficult to store and transport [52]. Physical damage is problematic because it allows microbial invasion and rotting of the internal starchy tissues. Controlling the temperature, water conditions, and hygiene are all necessary for long-term storage. Taro corms begin to rot as soon as two weeks after being harvested. Low storage temperatures cause sprouting and chill injuries, lowering the quality of stored corms. Working on shelf life, storage, and processing packages, for example, can help with food and nutritional security by reducing post-harvest losses.

\subsection{Acridity}

Despite its widespread use and high potential as a primary dietary source of carbohydrates and other essential nutrients, taro's use is frequently hampered by anti-nutrients, which are either potentially toxic or may limit nutrient bioavailability [53]. Oxalate, for example, is one of the anti-nutrient compounds (deadly organic acid) that have a significant impact on the eating quality of taro [54]. It occurs in two forms: soluble, producing salts with potassium, sodium, and $\mathrm{NH}_{4}$ ions, and insoluble, producing insoluble salts, primarily with calcium, but also with iron and magnesium [55]. The presence of oxalate in raw corms or leaves causes sharp irritation and a burning sensation in the mouth and throat. Taro oxalate content varies consistently and significantly with photosynthetic rate, carbohydrate metabolism, and protein synthesis [56]. Soluble oxalate levels in young taro leaves were found to be higher than in old taro leaves [57].

Peeling and heating are the two most common ways to remove acridity from taro corms or petioles when preparing them for eating. Before cooking mature blades in the Pacific Islands, it is customary to remove the main ribs and tips. The acridity is said to be reduced by these actions. Acridity is thought to be reduced by fermenting corm tissues and adding certain ingredients. When making poi, the majority of the acridity in the corms is likely removed by peeling and boiling prior to fermentation. Improving taro's acridity is a long-term solution. To remove the acridity of wild taro, it requires more time to cook. Thus, improving taro for low acridity content will increase taro consumption by addressing the issue of cooking time and energy required to cook it.
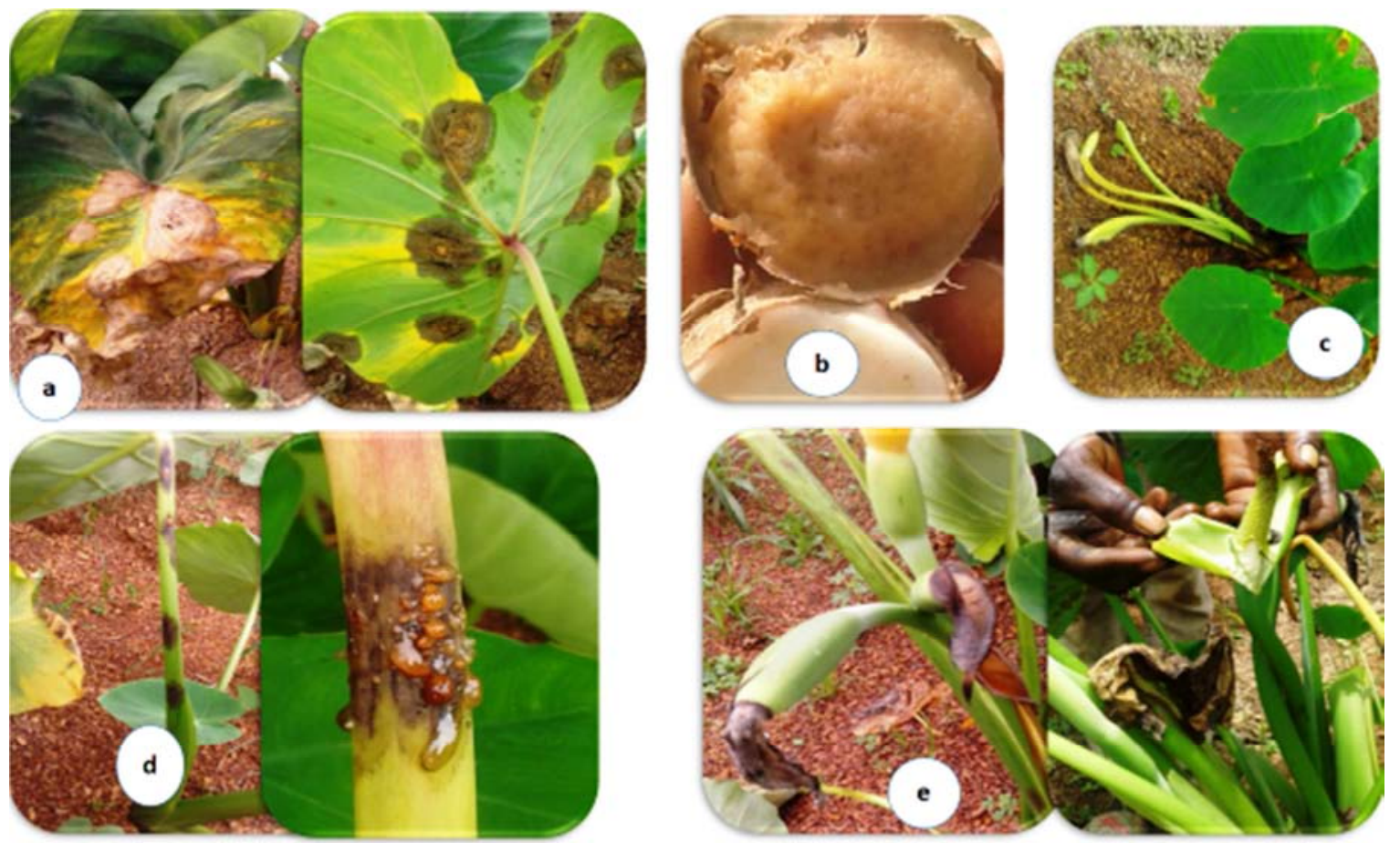

Figure 2. Lesions of taro leaf blight disease on different parts of taro plant. $a=$ leaf (upper and lower side), $b=c o r m, c=$ aborted flower stalk, $d=$ petiole (lesion on petiole and ooze on the lesion), $e=$ flower and fruits. 
Table 3. Review on taro production constraints and possible recommendations by countries.

\begin{tabular}{|c|c|c|c|}
\hline Country & Production constraints & Recommendation & Ref \\
\hline Papua New Guinea & Taro beetle, taro leaf blight and alomae bobone virus complex & $\begin{array}{l}\text { Improving taro accessions for pest and disease resistance } \\
\text { and implementing an integrated pest management system }\end{array}$ & {$[30]$} \\
\hline East Africa & Virus diseases & Virus indexing & {$[31]$} \\
\hline \multirow[t]{2}{*}{ Uganda } & $\begin{array}{l}\text { Less attention, shortage of cropland, lack of planting materials, } \\
\text { poor extension services and poor crop husbandry }\end{array}$ & $\begin{array}{l}\text { Improving taro for yield, pest and disease resistance, } \\
\text { anti-nutrient content, early maturation, and drought } \\
\text { tolerance }\end{array}$ & [32] \\
\hline & $\begin{array}{l}\text { Education level, wild animals, low yield, water logging, pests and } \\
\text { diseases, poor soil fertility }\end{array}$ & & [33] \\
\hline Togo & $\begin{array}{l}\text { Propagation materials, less promoted lack of information, lack of } \\
\text { preferred traits, weak breeding strategies, poor post-harvest } \\
\text { handling, rainfall irregularity, poor soil infertility and inefficient } \\
\text { marketing }\end{array}$ & $\begin{array}{l}\text { Improving productivity through molecular breeding } \\
\text { (marker assisted selection), food processing, and credit } \\
\text { availability }\end{array}$ & {$[34]$} \\
\hline Gahanna & $\begin{array}{l}\text { Accumulation of pest and diseases in planting material, low } \\
\text { productivity, lack of developed protocol for the rapid } \\
\text { multiplication of planting materials, high dormancy, poor soil } \\
\text { fertility, narrow genetic resources, weak ethno botanical } \\
\text { documentation, ineffective conservation, lack of awareness, lack } \\
\text { of diversified utilization, small scale production }\end{array}$ & $\begin{array}{l}\text { Improving yield, quality, pest and disease resistance, } \\
\text { germplasm collection and preservation, public awareness, } \\
\text { culinary diversity, soil management and fertilization, } \\
\text { tissue culture aid for micro propagation, and protocol } \\
\text { development }\end{array}$ & {$[35]$} \\
\hline $\begin{array}{l}\text { Nigeria, Cameroon, } \\
\text { the Democratic } \\
\text { Republic of Congo, } \\
\text { Kenya, and Tanzania }\end{array}$ & $\begin{array}{l}\text { Low palatability and inferior value, pest problems for its } \\
\text { conservation, insufficient knowledge on culinary and medicinal } \\
\text { uses, genetic losses, preference for youta than taro, diseases such } \\
\text { as the leaf blight and less effort to conserve landraces }\end{array}$ & $\begin{array}{l}\text { Disease resistance breeding, food processing research, } \\
\text { germplasm conservation, crop documentation, and crop } \\
\text { promotion }\end{array}$ & [36] \\
\hline Nigeria & $\begin{array}{l}\text { There is a lack of structured information on the diversity, cultivation, } \\
\text { trade, culinary, and medicinal uses of this crop, as well as a lack of } \\
\text { combined genetic and ethno botanical studies of this crop to link } \\
\text { cultivars to cultivation techniques, medicinal, and culinary uses }\end{array}$ & Food processing, pedigree record, and utilization studies & {$[37,38]$} \\
\hline \multirow{6}{*}{ Nigeria } & $\begin{array}{l}\text { Land size, lack of credit, farming experience, fertilizer, planting } \\
\text { materials, insufficient funds, and a high taro mortality rate }\end{array}$ & $\begin{array}{l}\text { Credit facility enhancements, crop promotion, crop } \\
\text { management practices, and post-harvest handling research }\end{array}$ & {$[39]$} \\
\hline & $\begin{array}{l}\text { Lack of farm inputs, high farm input costs, low soil fertility, land } \\
\text { constraints, labor constraints, poor access to information, } \\
\text { ineffectiveness of cooperatives, lack of funds or poor access to } \\
\text { funds, poor government support, lack of improved varieties, low } \\
\text { value attached to taro, insufficient infrastructure, technology } \\
\text { know-how, and transportation constraints }\end{array}$ & $\begin{array}{l}\text { Enrolment in cooperatives, revitalization of existing } \\
\text { cooperatives, re-orientation of farmers on the benefits of } \\
\text { taro, increased use of climate change information, } \\
\text { breeding for improved varieties, and sharing via mobile } \\
\text { phones are all potential solutions to the challenges }\end{array}$ & [40] \\
\hline & Disease and insects infestation & $\begin{array}{l}\text { Access to fungicides and insecticides, as well as the } \\
\text { development of resistant or tolerant hybrids }\end{array}$ & [41] \\
\hline & $\begin{array}{l}\text { Climate change, inconsistency in planting and harvesting dates, } \\
\text { nutrient deficiency (slowed growth), high post-harvest loss, } \\
\text { inadequate storage facilities (brans), and poor shelf life are all } \\
\text { factors to consider }\end{array}$ & $\begin{array}{l}\text { Crop management research, improvement toward early } \\
\text { maturity, access to inputs, subsidized input costs, and } \\
\text { improved storage facilities }\end{array}$ & [42] \\
\hline & The cost of input and the time it takes to supply input & $\begin{array}{l}\text { Fertilizer is delivered to farmers on time and in sufficient } \\
\text { quantities at a reasonable cost }\end{array}$ & {$[43]$} \\
\hline & High inorganic fertilizer costs, wilting, and late planting & $\begin{array}{l}\text { Policy options, increased productivity, access to inputs, } \\
\text { credit, and adequate motivation of extension agents }\end{array}$ & [44] \\
\hline
\end{tabular}

\section{Roadmap for an Up-Scale Production and Increased Adoption of Taro by Both Farmers and Consumers}

\subsection{Farmers and Consumers Should Be Educated on Nutritional Benefits of Taro}

The introduction of new crops such as cassava and rice, which are relatively higher yielding and have international research and development leverage, poses enormous challenges to taro's future as a major crop [5]. To increase taro production, the use and utilization of taro, as well as raising awareness among consumers and producers, should be prioritized in taro strategic development. Thus, increased focus on taro research will result in a better understanding of the crop's potential contributions to food security, health, and economic empowerment.

\subsection{Taro Improvement Should Target Farmers' and Consumers' Preferred Traits}

Taro breeding should focus on traits that are important to farmers and consumers, such as yield, nutritional quality, disease resistance, shelf life, and culinary variety [58]. To achieve all of these breeding objectives, the genetic base of taro must be expanded for future use in the development of new varieties for farmers. Sexual hybridization, mutation, and somaclonal variation can all be used to generate variation. It's also important to understand how marker-assisted selection can help with taro improvement. Participatory breeding, which involves all stakeholders such as researchers, consumers, and farmers, can also accelerate the adoption of new technologies. 


\subsection{Novel Product Development}

Taro industrial uses in the production of flour, baby foods, starch and non-starch products, biodegradables, and other novel products will reduce postharvest losses, increase taro production, and improve food and nutritional security $[59,60]$. Feasible strategies and effective measures should be developed to support and encourage farmers by increasing the added value of original taro products through varietal improvement and product processing. Taro biofortification, for example, enriching taro with minerals such as zinc and iron, will increase the value of taro usage. Preparing brand recipes can also increase the focus on taro production and utilization.

\subsection{Collection and Maintenance of Taro Germplasm}

Taro cultivation for food and nutritional security is becoming more popular around the world [61, 62]. Taro conservation receives little attention and thus remains orphaned. Taro conservation, on the other hand, is a prerequisite for taro breeding because it is important in varietal development. To benefit from taro breeding, it is prudent to support farmers' cultivar maintenance models in order to keep cultivars for long periods of time. It is also critical to establish and support an institution in charge of taro germplasm conservation.

\subsection{Promoting Traditional Diets Even in the Midst of Easy Growers}

The introduction and domestication of easy-to-grow crops is jeopardizing the acceptance and dominance of indigenous crops [62]. Growers will gain recognition and prominence as staple foods, eventually replacing the previous staples. Taro was a staple food in south-eastern Nigeria three decades ago. Nigerians have shifted away from their traditional diets, which included a variety of staple foods, and now eat primarily rice, cassava, and yams [5]. This resulted in a decrease in cultivation acreage, as well as the possible loss of cultivars and genetic diversity in the taro.

\subsection{Preserving Genetic and Culinary Diversity}

Agricultural institutions can play an important role in motivating cultivar preservation and culinary knowledge in existing taro-producing areas [63]. The role of plant breeders in increasing taro edibility by reducing acridity in the corms or leaves is also extensive. Because different cultivars are used in different ways, breeders should be aware of the varital differences and culinary variation used by farmers. By doing so, culinary knowledge is preserved, as is genetic diversity in the crop [1].

\section{Conclusion}

Undernourishment is a serious issue that affects millions of people worldwide. Underutilized crops, such as the taro plant, can play critical roles in the food and nutritional security of developing-country farmers with limited resources. Taro conservation receives little attention in Nigeria and thus goes unnoticed. Farmers, on the other hand, continue to conserve and use them. Growers in Igbo Land, for example, select and maintain taro based on morphological characteristics such as petiole color, bud color, corm shape, and the irritating nature of the taro. Farmers conserve taro in their backyard gardens, giving taro growers access to more genetic diversity. Farmers also prefer taro genotypes that are both robust and productive. Biological, abiotic, and social constraints all impede taro production. Low yield, disease, anti-nutrients, drought, and post-harvest losses are just a few of them. Traditional Nigerian diets have evolved to include a diverse range of staple foods. This could result in reduced cultivation acreage, as well as the loss of cultivars and genetic diversity. Crop conservation and utilization strategies should be developed to address the issue. Educating people, improving traits of interest, developing novel products, preserving taro genetic resources, and leveraging farmers' knowledge of crop conservation and utilization should be some of the future lines of work for Nigerian taro breeding and conservation strategies.

\section{Conflict of Interest}

All the authors do not have any possible conflicts of Interest.

\section{Acknowledgements}

The authors would like to thank the Tertiary Education Trust Fund (TETFUND) of Ebonyi State University in Abakaliki, Nigeria, for their assistance.

\section{References}

[1] Matthews, P. J., An introduction to the history of taro as a food. The Global Diversity of Taro, 2010. 6.

[2] Chaïr, H., et al., Genetic diversification and dispersal of taro (Colocasia esculenta (L.) Schott). PloS one, 2016. 11 (6).

[3] FAOSTAT, F., Crop statistics. 2018.

[4] Amadi, C. O., et al., Hybridization and Seed Germination of Taro (Colocasia Esculenta) in Nigeria. Journal of Crop Improvement, 2015. 29 (1): p. 106-116.

[5] Ubalua, A. O., F. Ewa, and O. D. Okeagu, Potentials and challenges of sustainable taro (Colocasia esculenta) production in Nigeria. Journal of Applied Biology and Biotechnology Vol, 2016.4 (01): p. 053-059.

[6] Dervis, S., S. Soylu, and C. U. Serce, Corm and root rot of Colocasia esculenta caused by Ovatisporangium vexans and Rhizoctonia solani. Romanian Biotechnological Letters, 2014. 19 (6): p. 9868-9874.

[7] Abdulrahman, S., A. Abdullahi, and B. Muhammad, Analysis of Constraints to Cocoyam Production in Kaduna State, Nigeria. Journal of Scientific Research and Reports, 2015. 6 (3): p. 211-216. 
[8] Chivenge, P., et al., The potential role of neglected and underutilised crop species as future crops under water scarce conditions in Sub-Saharan Africa. International journal of environmental research and public health, 2015. 12 (6): p. $5685-5711$.

[9] Tadele, Z., African orphan crops under abiotic stresses: challenges and opportunities. Scientifica, 2018. 2018.

[10] Miyasaka, S. C., et al., Genetic Diversity in Taro (Colocasia esculenta), in Genetic Diversity in Horticultural Plants. 2019, Springer. p. 191-215.

[11] Dai, H., et al., Two-step identification of taro (Colocasia esculenta cv. Xinmaoyu) using specific psbE-petL and simple sequence repeat-sequence characterized amplified regions (SSR-SCAR) markers. Genet Mol Res, 2016. 15: p. 1-10.

[12] Sarkar, N., N. Adhikary, and J. Tarafdar, Field management of taro leaf blight using promising germplasm. International journal of current microbiology and applied science. 6: 1399, 2017. 1407.

[13] Rao, V. R., et al., The Global Diversity of Taro: ethnobotany and conservation. 2010.

[14] Parvin, S., et al., Karyotype analysis of seven varieties of taro Colocasia esculenta (L.) Schott. from Bangladesh. Journal of Bio-Science, 2008. 16: p. 15-18.

[15] Jianchu, X., et al., Genetic diversity in taro (Colocasia esculenta Schott, Araceae) in China: An ethnobotanical and genetic approach. Economic Botany, 2001. 55 (1): p. 14-31.

[16] Lebot, V., et al., Characterizing taro using isozymes and morpho-agronomic descriptors. The Global Diversity of Taro, 2010: p. 39

[17] Manzano, A. R., et al., Morphological and isoenzyme variability of taro (Colocasia esculenta L. Schott) germplasm in Cuba. Plant genetic resources newsletter, 2001: p. 31-40.

[18] Beah, A. A., et al., Assessment of agro-morphological diversity and affinities in cocoyam species from Sierra Leone. International Journal of Biodiversity and Conservation, 2015. 7 (10): p. 408-419.

[19] Bhattacharjee, M., J. Tarafdar, and R. Sadhukhan, Assessment of genetic diversity of some indigenous collections of upland taro Colocassia esculenta var. antiquorium (L.) Schott for selection of genotypes aiming at improvement in breeding programme. IOSR Journal of Agriculture and Veterinary Science, 2014. 7 (7): p. 31-43.

[20] Orji, K. and P. Ogbonna, Morphological Correlation Analysis On Some Agronomic Traits Of Taro (Colocasia esculenta) In The Plains Of Nsukka, Nigeria. Journal of Global Biosciences, 2015. 4 (1): p. 1120-1126.

[21] Singh, D., et al., Taro leaf blight-a threat to food security. Agriculture, 2012. 2 (3): p. 182-203.

[22] Sthapit, B., V. R. Rao, and H. A. Lamers, Feasibility of Conservation of Horticultural Genetic Resources in In Situ/On Farm, in Conservation and Utilization of Horticultural Genetic Resources. 2019, Springer. p. 49-76.

[23] Taylor, M., et al., Taro collecting and conservation in the Pacific region. The Global Diversity of Taro, 2010. 150.

[24] Nand, A. V., et al., Isolation and properties of starch from some local cultivars of cassava and taro in Fiji. The South
Pacific Journal of Natural and Applied Sciences, 2008. 26 (1): p. $45-48$.

[25] Kaushal, P., V. Kumar, and H. Sharma, Utilization of taro (Colocasia esculenta): a review. Journal of Food Science and Technology, 2015. 52 (1): p. 27-40.

[26] Paul, K. and M. Miah, Genetic variability, correlation and path coefficient studies in elephant foot yam (Amorphophallus campanulatus Bl.). Journal of Scientific Research, 2013. 5 (2): p. $371-381$.

[27] Temesgen, M. and N. Retta, Nutritional potential, health and food security benefits of Taro Colocasia esculenta (L.): a review. Food Sci Qual Manag, 2015. 36.

[28] Chandrasekara, A. and T. Josheph Kumar, Roots and tuber crops as functional foods: a review on phytochemical constituents and their potential health benefits. International journal of food science, 2016. 2016.

[29] Rashmi, D., et al., Taro (Colocasia esculenta): an overview. Journal of Medicinal Plants Studies, 2018. 6 (4): p. 156-161.

[30] Sar, S., B. Wayi, and R. Ghodake, Review of research in Papua New Guinea for sustainable production of taro (Colocasia esculenta). TROPICAL AGRICULTURE-LONDON THEN TRINIDAD-, 1998. 75: p. 134-138.

[31] Kidanemariam, D. B., Viruses of taro and other edible aroids in east Africa. 2018, Queensland University of Technology.

[32] MosesBasoga, V. N. and E. Kamusiime, Assessment of Production Systems, Constraints and Farmers' Preferences for Taro (Colocasia esculenta (L.) Schott) in Uganda. 2016.

[33] Kasule, J., Factors affecting cocoyam production in Mityana district. 2019.

[34] Bammite, D., et al., Constraints to production and preferred traits for taro (Colocasia esculenta) and new cocoyam (Xanthosoma mafaffa) in Togo, west Africa. African Journal of Food, Agriculture, Nutrition and Development, 2018. 18 (2): p. 13388-13405.

[35] Sagoe, R., et al., Developing Low Input Technology for Rapid Multiplication of Taro (Colocasia esculenta) Planting Material. Agricultural and Food Science Journal of Ghana, 2018. 11 (1): p. $968-976$.

[36] Grimaldi, I. M., et al., From landraces to modern cultivars: field observations on taro Colocasia esculenta (L.) Schott in sub-Saharan Africa. Genetic Resources and Crop Evolution, 2018. 65 (7): p. 1809-1828.

[37] Grimaldi, I. M. and T. R. van Andel, Food and Medicine by What Name? Ethnobotanical and Linguistic Diversity of Taro in Africa. Economic Botany, 2018. 72 (2): p. 217-228.

[38] Suleman, A., Analysis of Rural Farmers' Use of Improved Cocoyam Production Practices in South-South, Nigeria. 2019, Federal University of Technology, Owerri.

[39] Nwakor, F., et al., Assessment of factors influencing cocoyam production among farmers in southeast zone of Nigeria. Journal of Agriculture and Social Research (JASR), 2016. 16 (2): p. 32-39.

[40] Ifeanyi-Obi, C., et al., Challenges faced by cocoyam farmers in adapting to climate change in Southeast Nigeria. Climate Risk Management, 2017. 17: p. 155-164. 
[41] Nwaobiala, C. U. and T. N. Uchechi, Utilization of cocoyam production technologies among women farmers in Abia State, Nigeria. Journal of Agricultural Extension, 2016. 20 (1): p. 13-26.

[42] Ifeanyi-obi, C., A. Togun, and R. Lamboll, Influence of Climate Change on Cocoyam Production in Aba Agricultural Zone of Abia State, Nigeria, in Innovation in Climate Change Adaptation. 2016, Springer. p. 261-273.

[43] Abdulrahman, S., et al., Technical Efficiency of Cocoyam Production in Kaduna State, Nigeria: A Stochastic Production Frontier Approach. Journal of Economics, Management and Trade, 2018: p. 1-10.

[44] Ikoro, P., M. Godwin-Egein, and U. Udensi, Farmers perception of cocoyam production constraints in ogbaland, Rivers State, Nigeria. African Journal of Agriculture Technology and Environment Vol, 2019. 8 (2): p. 106-115.

[45] Scot, N., F. Brooks, and T. Glenn, Taro Leaf Blight in Hawai'i. University of Hawai'i at Mänoa. Plant Disease, 2011. 71: p. $1-14$.

[46] Mbong, G., et al., An overview of Phytophthora colocasiae of cocoyams: A potential economic disease of food security in Cameroon. Discourse Journal of Agriculture and Food Sciences, 2013. 1 (9): p. 140-145.

[47] Misra, R. S., K. Sharma, and A. K. Mishra, Phytophthora leaf blight of Taro (Colocasia esculenta) - a review. Asian Australas J Plant Sci Biotechnol, 2008. 2: p. 55-63.

[48] Ganança, J. F. T., et al., Screening for drought tolerance in thirty three taro cultivars. Notulae Botanicae Horti Agrobotanici Cluj-Napoca, 2018. 46.

[49] Lebot, V., et al., Characterization of taro [Colocasia esculenta (L.) Schott] germplasm for improved flavonoid composition and content. Plant Genetic Resources, 2015. 15 (3): p. 260-268.

[50] Daryanto, S., L. Wang, and P.-A. Jacinthe, Drought effects on root and tuber production: A meta-analysis. Agricultural water management, 2016. 176: p. 122-131.

[51] Ganança, J. F. T., et al., Screening of elite and local taro (Colocasia esculenta) cultivars for drought tolerance. Procedia Environmental Sciences, 2015. 29: p. 41-42.

[52] Matthews, P. J., Taro storage systems. Vegeculture in Eastern Asia and Oceania (S. Yoshida and PJ Matthews, eds.). The Japan Center for Area Studies, Osaka, 2002: p. 135-163.
[53] Alcantara, R. M., W. A. Hurtada, and E. Dizon, The nutritional value and phytochemical components of taro [Colocasia esculenta (L.) Schott] powder and its selected processed foods. J Nutr Food Sci, 2013. 3 (207): p. 2.

[54] Lewu, M. N., P. O. Adebola, and A. J. Afolayan, Effect of cooking on the mineral and antinutrient contents of the leaves of seven accessions of Colocasia esculenta (L.) Schott growing in South Africa. Journal of Food, Agriculture \& Environment, 2009. 7 (3\&4): p. 359-363.

[55] Savage, G., et al., Effect of cooking on the soluble and insoluble oxalate content of some New Zealand foods. Journal of Food Composition and Analysis, 2000. 13 (3): p. 201-206.

[56] Gouveia, C. S., et al., Quantitation of oxalates in corms and shoots of Colocasia esculenta (L.) Schott under drought conditions. Acta physiologiae plantarum, 2018. 40 (12): p. 214.

[57] Oscarsson, K. and G. Savage, Composition and availability of soluble and insoluble oxalates in raw and cooked taro (Colocasia esculenta var. Schott) leaves. Food chemistry, 2007. 101 (2): p. 559-562.

[58] Mgbedike, N., et al., Strategies for Improving Cocoyam Production among Farmers in Anambra State, Nigeria. 2017.

[59] Owusu-Darko, P. G., A. Paterson, and E. L. Omenyo, Cocoyam (corms and cormels) - An underexploited food and feed resource. Journal of Agricultural Chemistry and Environment, 2014. 3 (01): p. 22.

[60] Yazid, N. S. M., et al., Application of starch and starch-based products in food industry. Journal of Science and Technology, 2018. 10 (2).

[61] Afari-Sefa, V., et al., Vegetable breeding in Africa: constraints, complexity and contributions toward achieving food and nutritional security. Food Security, 2012. 4 (1): p. 115-127.

[62] Mburu, S. W., et al., Agrobiodiversity conservation enhances food security in subsistence-based farming systems of Eastern Kenya. Agriculture \& Food Security, 2016. 5 (1): p. 19.

[63] Ebert, A. W. and L. M. Waqainabete, Conserving and sharing taro genetic resources for the benefit of global taro cultivation: a core contribution of the centre for Pacific crops and trees. Biopreservation and biobanking, 2018. 16 (5): p. 361-367. 